\title{
Aktualisasi Pelayanan Karunia di Era Digital
}

\author{
Harls Evan R. Siahaan \\ Sekolah Tinggi Teologi Intheos Surakarta \\ evandavidsiahaan@gmail.com
}

Article History

Received:

Mei 2017 (printed)

Published:

Mei 2017 (printed)

Keywords: digitalization; digital era; gift; ministry; the church; gift of writing

Kata kunci: digitilisasi; era digital; gereja; karunia; karunia menulis; pelayanan

\begin{abstract}
The Ministry of a Gift is a Christian ministry both inward and outward of the chuirch. It is a reflection of the gift God's given in related to Church ministry according to her need and the world's context where the church existed. This article purposed to show the reflection that the world which in digital era is requiring an actual form of ministry that the church must be responded and prepared it. This article employed a method of literature descriptive and analysis of world's context. The analysis result is that the church must establish and develop a gift of writing to God's people in order to develop their ministry.
\end{abstract}

\begin{abstract}
Abstrak
Pelayanan Karunia adalah sebuah bentuk pelayanan Kristiani, baik dalam konteks gereja maupun di luar gereja. Pelayanan karunia merupakan refleksi dari pengembangan karunia yang Tuhan sediakan berkaitan dengan pelayanan sesuai dengan kebutuhan gereja dan konteks dunia di mana gereja berada. Artikel ini bertujuan untuk menunjukkan secara reflektif, bahwa dunia yang sudah memasuki era digital ini membutuhkan sebuah bentuk pelayanan aktual yang harus ditanggapi dan dipersiapkan oleh gereja. Metode dalam penelitian literatur ini adalah deskriptif dan analisis. Temuan dalam kajian analisis reflektif ini diperoleh, bahwa gereja harus mengembangkan karunia menulis bagi umat Tuhan agar dapat mengembangkan pelayanannya.
\end{abstract}

\section{Pendahuluan}

Melayani adalah suatu bentuk atau praktik yang dapat dilakukan setiap orang sebagai ungkapan rasa terima kasih kepada Tuhan. Melayani juga dapat disebut sebagai bentuk kasih kepada Tuhan, sekalipun kasih yang dilakukan oleh manusia kepada Tuhan itu tidaklah sebanding dengan apa yang telah Tuhan lakukan. Dengan melayani 
seseorang dapat menyenangkan hati Tuhan, dengan talenta yang telah dikaruniakan-Nya kepada setiap orang. Semua orang di gereja memiliki kesempatan untuk melayani Tuhan. Setiap orang memiliki panggilan dalam melayani Tuhan, di mana masingmasing orang memiliki panggilan yang berbeda satu dengan lainnya. Namun demikian, tidak semua jemaat ingin terlibat dalam melayani Tuhan. Tidak sedikit yang berpikir bahwa melayani adalah pekerjaan pendeta atau para hamba Tuhan saja.

Pemahaman tentang pelayanan hanyalah pekerjaan para pendeta atau hamba Tuhan tidakah sepenuhnya salah. Karena memang sejatinya seorang pendeta atau hamba Tuhan adalah mereka yang memiliki panggilan atau komitmen untuk memberikan hidupnya melayani Tuhan. Tidak sedikit gereja yang mendorong jemaat kaum awam untuk terlibat dalam pelayanan secara full time, menjadi staf pastoral atau menangani pekerjaan di kantor gereja. Pelayanan yang tersedia di masing-masing gereja tidaklah sama satu dengan yang lainnya, tergantung pada kebutuhan umat dan kemampuan yang dimiliki oleh gereja tersebut.

Seiring dengan perkembangan zaman yang semakin canggih pada saat ini, maka ada perbedaan dan pergeseran budaya serta kebutuhan yang ada di dalam gereja. Contoh saja, dulu ketika gereja masih ditangani secara sederhana, maka seorang gembala sidang dapat melakukan fungsi yang beragam (one man show), artinya pendeta menangani semua jenis pekerjaan yang ada di dalam pelayanan. Namun kemajuan ilmu pengetahuan telah membuat pelayanan dapat dilakukan secara teratur, dengan menerapkan prinsip manajemen dan pendelegasian. Dulu ketika menyanyikan pujian menggunakan buku, maka tidak ada kebutuhan seorang operator yang mengoperasikan LCD Projector sebagai pengganti buku pujian di zaman sekarang. Kebutuhan gereja berbeda sesuai dengan perkembangan zamannya.

Sistem yang menerapkan manajemen dalam pelayanan gereja juga tidaklah salah. Gereja yang besar dan terus berkembang membutuhkan banyak tenaga yang kompeten di bidangnya, sehingga harus ada yang mengatur semua orang yang melayani. Tidak hanya gereja besar yang menerapkan manajemen dalam gereja, karena pada prinsipnya semua pelayanan harus tertata rapi dan berjalan dengan baik. Sehingga pelayan dapat menyentuh semua kebutuhan umat. Istilahnya adalah, pelayanan yang holistik. Eka Darma Putera mengatakan, "Holistik artinya melihat kebutuhan mannusia baik kebutuhan-kebutuhan individualnya maupun sosialnya, kebutuhan fisik, psikis, maupun kebutuhan spiritualnya, kebutuhan sekarang di bumi maupun kebutuhan nanti setelah 
mati, dan sebagainya." Namun tidak sedikit juga gereja yang belum menerapkan manajemen pelayanan.

Pelayanan di gereja yang besar sangat membutuhkan manajemen pelayanan, karena ada banyak bidang yang harus dapat ditangani oleh orang-orang yang kompeten di bidangnya. Apalagi pelayanan yang dilakukan tersebut harus bersifat profesional. Artinya, para pelayan Tuhan memiliki kemauan dan kemampuan yang baik dalam melayani di bidangnya masing-masing. Masing-masing harus dapat menunjukkan pelayanannya yang terbaik. Tanpa disadari muncul semacam kecenderungan untuk bersaing antar satu pelayan dengan yang lain. Sejauh persaingan itu bersifat sehat dan untuk mengembangkan pelayanan yang dipercayakan, maka hal tersebut baik. Pemimpin pelayan harus dapat menghindari persaingan tidak sehat yang mungkin muncul di antara pelayan Tuhan di gereja.

Frederick K.C. mengatakan: “...adanya persaingan para pelayan berusaha menjadi lain dari rekan - rekannya demi memikat atau dipandang lebih." Para pelayan Tuhan, bahkan pendeta sekalipun, masih memiliki kelemahan secara kedagingan, keinginan untuk menonjolkan diri, dikenal, bahkan dipuji. Keinginan tersebut lama kelamaan dapat merusak motivasi dalam melayani Tuhan. Rasa kasih kepada Tuhan beralih menjadi mengasihi diri sendiri, karena pusat pelayanan sudah bergeser kepada diri sendiri. Tidak sedikit motivasi pelayanan hanyalah sebuah pencapaian atau pendapatan secara materi.

Selain itu juga terjadi semacam fenomena, di mana orang-orang yang melayani lebih menyukai pelayanan mimbar, karena mereka tampil dan perhatikan jemaat. Memilih pelayanan untuk menjadi song leader, singers, atau pemain musik tidaklah salah, karena semua itu adalah pelayanan yang disediakan bagi siapa saja yang mampu dan memiliki talenta. Namun pemimpin pelayanan, dalam hal ini gembala sidang, harus dapat terus memberikan motivasi kepada para pelayan Tuhan, agar melayani secara tulus dan penuh kasih. Sehingga gereja dapat menekankan kemurnian motivasi dalam melayani Tuhan.

Seorang gembala sidang adalah pemimpin pelayanan dalam gereja, yang memegang otoritas dalam pelayanan di gereja lokal. Pemimpin tidak harus bertindak seperti layaknya seorang "Boss", sehingga yang ada hanyalah sikap memerintah.

\footnotetext{
${ }^{1}$ Eka Darma Putra, jurnal pelita zaman (Bandung:1988), 94.

${ }^{2}$ Frederick K.C, Saran-saran Praktis untuk Pelayanan yang Berhasil. (Jakarta: Yayasan Pekabaran Injil, 1993), 45.
} 
Seorang pemimpin gerejawi merupakan pelayan Tuhan yang harus membuang sikap memerintah, karena pada dasarnya memerintah bertentangan dengan prinsip melayani. J.L. Ch. Abineno mengatakan, "Jabatan gerejawi yang didapatkan tidak memberikan hak kepada pelayan untuk memerintah: memerintah atau saling memerintah. Pejabat gerejawi ialah melayani dan melayani adalah sebaliknya dari memerintah."3 Pelayanan harus ditandai dengan tindakan yang mencerminkan kerendahan hati. Harus diakui, masih banyak pelayan Tuhan atau hamba Tuhan yang kurang memiliki penundukkan diri.

Seorang hamba hanya mengikuti tuannya, demikian juga yang terjadi dengan hamba Tuhan. Tuhan sebagai tuan dalam pekerjaan yang dilakukan oleh hamba, memberikan perintah apa yang harus dilakukan dan kemana harus pergi. Hamba akan ikut saja dengan tidak banyak pertimbangan. Yesus pernah mengatakan kepada para murid-murid tentang sebuah perintah dalam pengutusan mereka, demikian: kata-Nya kepada mereka: "Jangan membawa apa-apa dalam perjalanan, jangan membawa tongkat atau bekal, roti atau uang, atau dua helai baju" (Luk 9:3). Dengan perintah seperti itu, maka para murid yang melayani sebagai hamba dari Yesus Kristus hanya ikut saja.

Terkadang muncul sebuah persoalan ketika hamba Tuhan diutus ke sebuah tempat dan tempat itu sepertinya tidak sesuai dengan pikirannya, maka ia mulai beralasan untuk menhindari. Hal ini seperti yang dikatakan oleh Phill M. Sulu,

Adakalahnya ada Hamba Tuhan yang ketika diminta melayani sebuah jemaat, berdalih hendak mencari kehendak Tuhan dahulu. Maksudnya hendak bertanya kepada Tuhan apakah dia cocok ditempatkan di tempat pelayanan itu atau tidak. Padahal dalam benaknya hendak mempelajari dahulu bagaimana rupa dan kondisi jemaat yang akan dilayani itu. ${ }^{4}$

Memang tidak semua hamba Tuhan seperti itu, karena masih banyak yang tulus melakukan pelayanan dengan mengandalkan tuntunan Tuhan. Konsep pelayanan seorang hamba harus diterapkan dalam diri setiap hamba Tuhan dan para pelayan yang melayani di dalam gereja.

Pelayanan di dalam gereja juga bentuknya beragam, sesuai dengan kemampuan serta talenta yang dimiliki oleh setiap orang yang melayani. Terkadang ada kesempatan di mana orang harus melakukan hal yang kecil sebelum akhirnya ia diangkat ke tempat yang lebih besar dan bagus. Ini tidak berarti bahwa pelayanan itu ada tingkatannya,

\footnotetext{
${ }^{3}$ Dr. J. Ch. Abineno. Penatua jabatannya dan pekerjaannya. (jakarta: BPK Gunung mulia, 1997), 24

${ }^{4}$ Phill. M. Sulu, Gembala dimata Jemaat, (Malang:Gandum Mas, 2014), 11.
} 
karena pada prinsipnya semua pelayanan sama di mata Tuhan. Namun dalam proses seringkali untuk mendapatkan tempat yang dianggap sesuai dengan talentanya, seorang hamba atau pelayan Tuhan harus setia melakukan perkara yang kecil terlebih dahulu.

Pelayanan dalam bentuk apa pun pada dasarnya adalah sebuah bentuk pengabdian, ungkapan syukur kepada Tuhan oleh karena anugerah yang tidak terbalaskan itu. Dalam melayani, seorang hamba hanya melihat kepada tuannya saja, yakni Tuhan Yesus Kristus, tanpa mempertimbangkan apa yang seharusnya didapatkan. Seorang yang melayani Tuhan tidak menonjolkan dirinya, melainkan hanya sematamata mengungkapkan rasa kasih yang besar kepada Tuhan Yesus sebagai tuan yang dilayani. Pergeseran nilai-nilai budaya dan sosial telah memunculkan masyarakat yang penuh dengan nilai-nilai pragmatis, sehingga gereja pun terimbas.

Gereja berada di tengah masyarakat yang sedang mengalami perubahan dan pergeseran nilai-nilai zaman. Selain itu gereja juga sedang berada dalam sebuah situasi di mana kemajuan dalam setiap aspek dan dimensi bidang kehidupan demikian terasa, terutama pada bidang ilmu dan teknologi (Iptek). Kemajuan teknologi yang paling terasa mengubah keadaan zaman adalah pada bidang informasi. Kemajuannya telah menghasilkan sebuah era komunikasi yang semakin canggih dan membuat dunia begitu kecil karena cakupannya yang demikian mengglobal. Kemajuan di segala lini kehidupan ini tentunya menuntut sebuah adaptasi yang sama di dunia pelayanan.

Gereja diperhadapkan pada bentuk dunia yang mengglobal, sehingga bentuk pelayanannya pun tidak lagi menerapkan sistem yang terkesan usang dalam masyarakat. Ada kebutuhan yang semakin pelik dan kompleks dalam diri manusia yang sekaligus adalah anggota gereja. Artinya, kebutuhan pelayanan di era yang semakin maju dengan teknologi digitalnya telah menuntut sebuah pengembangan sekaligus kemajuan dalam prinsip melayani. Gereja harus berbenah untuk melihat kebutuhan tersebut. Itu sebabnya diperlukan sebuah aktualisasi bentuk pelayanan yang menjawab sebuah tantangan dari kemajuan zaman ini.

Pelayanan gerejawi dalam bentuk yang beragam merupakan sebuah implementasi dari panggilan terhadap bentuk pelayanan tersebut. Masing-masing bidang pelayanan merupakan refleksi dari kehasan masing-masing orang yang menanganinya. Pelayanan didasarkan pada sebuah panggilan yang khas pada tiap orang, di mana dalam panggilan tersebut diekspresikan karunia yang berbeda-beda. Artinya, 
setiap pelayanan membutuhkan sebuah karunia yang khas. Karunia diberikan untuk manusia dapat melakukan panggilan pelayanannya.

Berbagai masalah yang berkaitan dengan pelayanan gerejawi dan kemajuan zaman telah memunculkan tantangan dan persoalan bagi para pelayan Tuhan khususnya. Tantangan itu merupakan ekspresi dari kebutuhan gereja dan pelayanan yang ada di dalamnya. Pelbagai persoalan dan masalah yang telah diurai dalam latar belakang di atas akan dibatasi pada tantangan atau kebutuhan pelayanan dengan kemajuan teknologi digitalnya saat ini. Kemajuan teknologi digital di segala bidang, terutama informasi telah menghasilkan pergeseran budaya dan sekaligus membawa gereja masuk ke dalamnya. Itu sebabnya penelitian ini dibatasai pada pertanyaan: Bentuk pelayanan seperti apa yang aktual pada konteks kemajuan teknologi digital masa kini?

Tujuan penelitian jelas yang pertama adalah untuk menunjukkan dan menjelaskan refleksi biblikal terhadap pelayanan gerejawi yang dilandaskan pada karunia. Dengan kata lain, setiap bidang pelayanan membutuhkan karunia khusus untuk menanganinya. Kedua, bentuk pelayanan dengan karunia seperti apa yang aktual dalam konteks kemajuan teknologi digital masa kini.

Penelitian ini juga memberikan manfaat, baik secara teoretis dan praksis. Secara teoretis, penelitian ini akan memberikan kontribusi dan rekomendasi dalam perkuliahan Studi Pelayanan Karunia yang diampuh oleh penulis di Sekolah Tinggi Teologi Intheos tahun 2016/2017. Secara praksis, penelitian ini juga akan memberikan manfaat bagi para hamba Tuhan, agar dapat mempertajam secara aktual dan mengembangkan pelayanannya di era yang semakin maju secara teknologi digital ini. Selain itu, gereja dapat mengajarkan dan menstimulasi jemaat, serta memperlengkapi mereka untuk dapat melayani Tuhan sesuai dengan karunia yang menjawab tantangan kemajuan teknologi digital. Bagi institusi Sekolah Tinggi Teologi dan para mahasiswa dapat memberikan simulasi pelayanan yang aktual di era digital.

\section{Metodologi}

Penelitian ini merupakan penelitian fenomenologis dengan pendekatan kualitatif secara literatur untuk menjelaskan dan menganalisis perkembangan zaman yang mempengaruhi berbagai kebutuhan pelayanan gerejawi. Penelitian ini menggunakan kajian biblikal yang bersifat tematik untuk menjelaskan landasan pelayanan berdasarkan 
karunia. Kemudian menganalisis fenomena kemajuan teknologi digital yang membuat perubahan dan kemajuan pada semua dimensi dan bidang kehidupan, sekaligus mempengaruhi kebutuhan pelayanan gerejawi yang sesuai dengan kemajuan zaman ini.

\section{Pembahasan}

Gereja merupakan bagian dari masyarakat dunia yang global, di mana memasuki abad ke-21 kemajuannya semakin terasa di setiap dimensi kehidupan manusia. Dunia di mana gereja lahir sudah jauh berbeda dengan keadaan sekarang ini. Hal ini jelas berdampak terhadap bentuk pelayanan yang ada di dalam gereja. Kemajuan teknologi yang dirasakan dunia hari ini mengakibatkan perkembangan kebutuhan yang semakin kompleks. Demikian juga gereja yang ada di dalam dunia, harus dapat menempatkan diri secara dinamis.

Gereja tidak terhanyut oleh perkembangan dan perubahan secara masif belakangan ini, namun menjawabnya secara bijak hingga tetap dapat menggarami zaman yang ada sekarang ini. Menempatkan diri secara tepat pada konteks zaman dan kebutuhannya merupakan tugas dan tanggung jawab gereja dalam setiap zamannya. Namun bagaimana bentuk atau aktualisasi dalam rangka menjawab tantangan perubahan zaman, hal tersebut merupakan bentuk yang harus diperhatikan, karena setiap zaman memiliki tantangan dan kebutuhan yang berbeda-beda.

Ketika Tuhan memanggil dan membentuk umatNya (1 Pet. 2:9) yang disebut gereja, maka panggilan itu dilengkapi dengan karunia. Karunia diberikan kepada setiap orang yang ada di dalam gereja, dengan tujuan utama agar semua orang percaya dapat menjadikan dirinya saksi Kristus.

\section{Pelayanan Karunia}

Apa yang dimaksud pelayanan karunia? Pemikirannya sederhana saja, bahwa setiap orang yang melayani Tuhan, bidang apa pun itu, ditentukan oleh karunianya. Istilah ditentukan di sini lebih kepada di-drive untuk memperoleh hasil yang maksimal. Seorang yang dipanggil untuk melayani pastinya telah diperlengkapi minimal satu karunia dalam melayani. Karena, panggilan itu merupakan perwujudan dari karunia yang Tuhan berikan kepada seseorang untuk melayani. Karunia dapat berupa talenta atau "keahlian" yang Tuhan beri secara khas dan khusus kepada orang tertentu. 
Karunia secara umum berasal dari istilah Yunani $\chi a \rho \iota \sigma \mu a ́ \tau \omega \nu$ (kharismaton), yang berasal dari akar kata charis, yang berarti karunia, kasih karunia. Dalam Perjanjian Baru, kata ini umumnya dipergunakan untuk menyatakan kasih karunia yang dengan perantaraan Yesus Kristus dikerjakan dan dilimpahkan karunia ini oleh Iman (Rom.

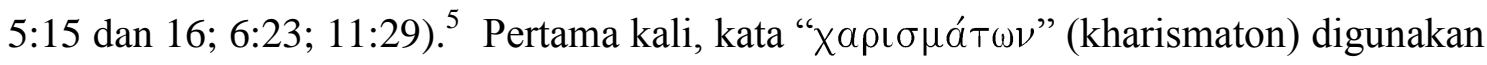
untuk menjelaskan "a gift (freely and graciously given), a favor bestowed; The spiritual

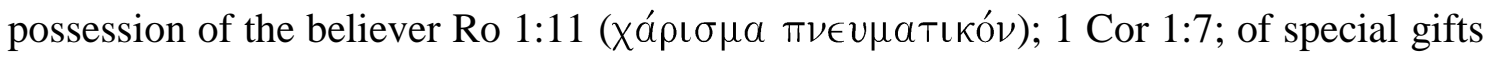
of a non-material sort, bestowed by the grace of God on individual Christian."6 Karunia adalah anugerah yang diberikan secara cuma-cuma kepada orang percaya secara individu. Karunia ini berupa non material karena bersifat spiritual supernatural yang akan memampukan orang percaya melakukan perkara-perkara supernatural dan diluar akal manusia pada umumnya.

Paul Enns menambahkan "He gives gifts. The Holy Spirit sovereignly dispenses spiritual abilities to believers (1 Cor. 12:4, 7, 11). He fills. The Holy Spirit controls believers when conditions are met (Eph. 5:18). He empowers. The Holy Spirit enables believers to live by His power (Gal. 5:16)."7 Sedangkan Dianne Bergant memberikan pengartian istilah " $\chi \alpha \rho \iota \sigma \mu \alpha ́ \tau \omega \nu "$ (kharismaton) yakni "Dari definisnya sendiri, kharismata merupakan perwujudan atau konkretisasi Roh (berarti masing-masing menerima sebagai karunia pribadi), yang dimaksudkan semata-mata demi pembangunan

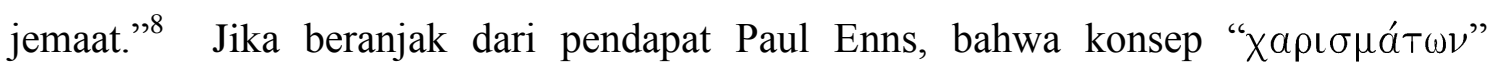
(kharismaton), di mana Roh Kudus memenuhi kehidupan orang percaya untuk mengendalikan hidup orang percaya dan Roh Kudus juga yang memberikan kekuatan kepada orang percaya sehingga mampu melayani gereja Tuhan.

Karunia merupakan pekerjaan Roh Allah, di mana secara jelas diungkapkan oleh Donald Guthrie yaitu "Sifat dasar kharismata ialah karuania-karunia itu merupakan pekerjaan Roh Allah yang diprakarsai oleh Allah sendiri, dan karena itu harus dibuat perbedaan antara kharismata dan karunia-karunia alamiah." 9 Istilah karismata sebagai karunia Allah digunakan untuk membedakan dengan karunia-karunia alamiah yang seharusnya dimengerti dengan bakat alam atau talenta. Jadi karunia itu bisa saja menjadi

\footnotetext{
${ }^{5}$ Brink H.v.d., Tafsiran Alkitab Kisah Para Rasul (Jakarta: BPK Gunung Mulia, 2008), 140

${ }^{6}$ Walter Bauer, F. Wilbur Gingrich, and Frederick W. Danker, A Greek-English Lexicon of the New Testament and Other Early Christian Literature, (Chicago: University of Chicago Press, 1979),

${ }^{7}$ Enns, Paul, The Moody Handbook of Theology, (Chicago, Ill.: Moody Press, 1996)

${ }^{8}$ Bergant, Op.cit., 265

${ }^{9}$ Donald Guthrie, Teologi Perjanjian Baru, 3 Jilid. (Jakarta: BPK Gunung Mulia, 1997), III: 95
} 
"kemampuan" seseorang karena Allah telah memberikannya kepadanya sebagai bagian hidupnya dalam melayani Tuhan. Karunia bersifat khas dan unik, berbeda satu dengan lainnya.

Jika hal ini dikaitkan dengan pelayanan, berarti pelayanan yang dilakukan seseorang bersifat unik dan tidak dapat dibandingkan dengan yang lain, karena Allah memiliki alasan untuk memberikan karuni itu kepada mereka. Namun demikian, karunia dalam konteks melayani dapat dikejar atau diupayakan dalam diri seseorang. Pelayanan karunia menjadi sebuah terminologi, bahwa seseorang melayani atau melakukan pekerjaan Tuhan sesuai dengan karunia yang diberikan Tuhan kepadanya.

\section{Tujuan dan Manfaat Pelayanan Karunia}

Tujuan pelayanan karunia sudah jelas untuk mengembangkan pelayanan, dan memaksimalkan seseorang dalam melayani Tuhan. Seorang yang melayani dengan karunianya akan memperoleh hasil yang maksimal dibandingkan dengan orang yang hanya sekadar hobby. Karunia merupakan cara Tuhan untuk mengembangkan gerejaNya, baik dalam pengertian pribadi maupun persekutuan orang percaya. Karena pada dasarnya karunia diberikan untuk mengembangkan diri orang yang diberi karunia (personal), mengembangkan jemaat atau gereja secara internal dan pengembangan secara eksternal. ${ }^{10}$ Allah memberikan karuniaNya untuk kebutuhan gerejaNya di dalam dunia, untuk mengerjakan tugas dan misi ilahi yang ada pada panggilan gereja.

Pelayanan karunia sangat bermanfaat bagi orang percaya, selain diri sendiri dikembangkan, maka komunitas di mana orang itu berada pun akan merasakan dampaknya. Itu sebabnya, dalam konteks perkuliahan di Sekolah Tinggi Teologi Intheos Surakarta, pada mata kuliah Studi Pelayanan Karunia, pemberdayaan masyarakat gereja harus dimulai dari pemberdayaan pemimpin atau pelayan Tuhan yang ada di gereja itu. Mahasiswa merupakan pemimpin dalam pelayanan yang dipercayakannya, dan mereka harus mampu melakukan simulasi dalam dirinya sebelum akhirnya kepada orang lain.

Di dalam perkuliahan Studi Pelayanan Karunia, mahaiswa didorong untuk pertama kali mampu menemukan jenis karunianya, sehingga ia memamksimalkan

\footnotetext{
${ }^{10}$ Johny Sumarauw, Made Astika, and Made Astika, “Analisis Pendayagunaan Karunia-Karunia Roh Terhadap Pertumbuhan Jemaat Gereja Pantekosta Di Indonesia El-Shaddai Makassar," Jurnal Jaffray 13, no. 1 (March 18, 2015): 55, accessed April 11, 2016, http://ojs.sttjaffray.ac.id/index.php/JJV71/article/view/113.
} 
dirinya sebelum memaksimalkan pelayanannya. Tanpa karunia pelayanan terhadap tubuh Kristus tidak dapat dikembangkan dan berhenti (stagnan). ${ }^{11}$ Hal ini dikarenakan Tuhanlah yang memiliki semua proyek ilahi dalam bentuk pelayanan yang dikerjakan gereja Tuhan, sehingga hanya Dia yang mengerti apa yang harus dilakukan dan digunakan dalam mengembangkan sebuah pelayanan.

Karunia pelayanan memberikan kesempatan bagi setiap orang yang melayani menyadari keterbatasannya dan bergantung pada yang tak terbatas untuk melakukan sebuah terobosan dalam kebuntuan pelayanan. Dan pada akhirnya, karunia itu akan memaksimalkan seseorang dalam melakukan pelayanan. Contoh sederhana, jika seorang diberikan karunia kesembuhan dalam melayani, maka ia tidak akan maksimal jika hanya berkecimpung dalam dunia akademis saja; ia harus masuk ke dunia pastoral atau misi.

\section{Karunia Melayani: Refleksi Alkitabiah}

Alkitab memang tidak membatasi ada berapa jenis atau jumlah karunia dalam melayani Tuhan. Sekalipun mungkin mampu dihitung jumlahnya dalam Alkitab namun tetap saja itu tidak merefleksikan tentang jumlah karunia yang disediakan bagi jemaat Tuhan. Pemikirannya, bahwa setiap karunia yang diberikan disebabkan oleh adanya kebutuhan. Pelayanan karunia dan kebutuhan gereja merupakan dua hal yang dapat dipisahkan, karena memiliki korelasi dua arah timbal balik. Kebutuhan jemaat akan peningkatan kualitas hidup secara pendidikan akan memunculkan karunia pengajar, begitu seterusnya.

Setidaknya ada tiga tempat dalam Perjanjian Baru tentang penyebutan karunia yang berkaitan dengan melayani, yakni: Roma 12, 1 Korintus 12, dan Efesus 4. ${ }^{12}$ Daftarnya secara umum seperti ini: Nubuat, pelayanan, mengajar, memberi nasihat, membagi-bagikan, kepemimpinan, kemurahan (Rom 12), hikmat, pengetahuan, imna, penyembuhan, mukjizat, membedakan roh, bahasa roh, menafsirkan bahasa roh, rasul, pertolongan, kepengurusan (1 Kor. 12), pemberita Injil, gembala (Ef 4). Selain itu juga ada jenis-jenis yang tidak tertulis langsung dalam Alkitab seperti: hidup melajang (selibat), hidup miskin secara suka rela, mati sebagai martir, memberi tumpangan, misionaris, doa syafaat, pelepasan. ${ }^{13}$ Daftar ini masih dapat terus diisi, karena karunia

\footnotetext{
${ }^{11}$ Ibid.

${ }^{12}$ Peter Wagner, Manfaat Karunia Roh (Malang: Gandum Mas, 200), 57-58

${ }^{13}$ Ibid., 61-75
} 
yang Allah berikan tidak dapat dibatasi. Itu akan terus berkembang sesuai dengan perubahan zaman.

Dunia digital telah menghadirkan kebutuhan yang lebih kontekstual dan menambahkan daftar yang sudah ada sebelumnya. Pelayanan ini harus cepat ditanggapi oleh gereja jika tidak ingin ditinggalkan dan ketinggalan. Agama lain telah mengadakan berbagai strategi demi untuk mengembangkan pelayanan mereka, tanpa harus menjadi kebarat-baratan. Kemajuan teknologi komunikasi membuat sebuah rangsangan positif untuk mengembangkan syiar Islam bagi kelompok akademisi Islam. ${ }^{14}$ Bagaimana dengan gereja dan kekristenan?

\section{Gereja dan Dunia di Era Digital}

Gereja dan dunia tidak dapat dipisahkan dalam konteks penelitian ini, karena bagaimana gereja menjalankan fungsinya itu berkaitan erat dengan dunia. Yesus mengatakan bahwa gereja memang ada di dunia tetapi bukan berasal dari dunia (Yoh 15:19). Dunia di mana gereja ada sekarang telah berubah dari masa ke masa, sehingga memberikan nuansa yang beragam pula. Gereja merupakan bagian dari rencana Allah yang besar, tentang keselamatan seluruh umat manusia. Gereja juga sebagai partner ilahi dalam mewujudkan rencana besar itu. Itu sebagnya keberadaan gereja dan dunia adalah dua hal yang akan senantiasa berkaitan. Gereja yang ada di dalam dunia tidak perlu menjadi duniawi.

Perkembangan dan kemajuan dunia oleh teknologi menjadi obyek pelayanan gerejawi di masa kini. Pelayanan pada masa gereja mula-mula sudah sangat jauh berbeda secara struktur dan teknis dengan yang ada sekarang. Namun secara prinsip, pelayanan merupakan bentuk yang berkesinambungan dengan benang merah yang konstan dari masa ke masa. Pendek kata, dunia dengan kemajuan teknologi yang disebut dengan teknologi digital telah memberikan identitas dunia di mana gereja melayani sekarang ini dengan istilah era digital.

Istilah era digital tidak lepas dari implementasi kecanggihan teknologi informasi yang telah menyentuh semua sendi kehidupan manusia, di mana semua sistem yang dijalankan secara manual dan memakan waktu, sekarang sudah demikian otomatis dan cepat dengan digitalisasi. Digitalisasi adalah proses di mana semua bentuk informasi

\footnotetext{
${ }^{14}$ Andi Faisal Bakti dan Venny Eka Meidasari, “Trendsetter Komunikasi Di Era Digital: Tantangan Dan Peluang Pendidikan Komunikasi Dan Penyiaran Islam,” Jurnal Komunikasi Islam 4, no. 1 (June 1, 2014), accessed Mei 23, 2015, http://jki.uinsby.ac.id/index.php/jki/article/view/35/29.
} 
baik angka, kata, gambar, suara, data, atau gerak dikodekan ke dalam bentuk bit (binary digit atau yang biasa disimbolisasikan dengan representasi 0 dan 1) yang memungkinkan manipulasi dan transformasi data (bitstreaming). ${ }^{15}$ Digitalisasi semua perangkat hidup manusia dengan kecanggihan teknologi secara otomatis juga mendigitalisasi masyarakatnya, termasuk gereja yang ada di dalamnya.

Gereja diperhadapkan dengan dunia yang sedang mengalami perubahan besar dan berlari secepat kuda (band. Yer 12:5a); apakah mau terlibat atau penonton. Sayangnya, gereja memiliki panggilan untuk melayani dunia. Konsekuensinya gereja harus tetap ada dalam perubahan yang ditawarkan dunia tanpa harus menjadi duniawi. Gereja harus menanggapi perubahan dan kemajuan ini dengan bijak sehingga mampu menjadi pelayan yang baik bagi dunia. Ini berarti gereja harus bisa menyesuaikan diri dengan berbagai kebutuhan dunia yang kompleks dan serba digit. Tantangan yang ada dapat menjadi sebuah kesempatan untuk berbenah dan meningkatkan kualitas pelayanan gereja, baik ke dalam maupun mengembangkan pelayanan lain secara misiologis.

\section{Gereja dan Tantangan Digitalisasi}

Tantangan gereja memasuki era digital semakin kompleks dan luas. Perkembangan teknologi sudah memberikan perbedaan dalam cara beribadah yang dilakukan gereja sekarang dengan gereja pada awal abad 20. Jemaat sekarang ini sudah jarang membawa Alkitab ke gereja, apalagi buku nyanyian, karena semua hal tersebut sudah terbalut oleh kemajuan teknologi yang semakin memudahkan orang untuk bergereja. ${ }^{16}$ Hal ini tidak dapat dinilai dengan pola bergereja masa reformasi atau lahirnya kegerakan Pentakosta modern, di mana orang didorong untuk giat dalam membaca Alkitab sehingga mereka selalu membawa Alkitab dalam bentuk konvensional. Mereka membawa semuanya itu dalam satu perangkat gadget yang sudah semakin canggih. Semuanya mengalami pergeseran seiring berubahnya nuansa zaman.

Ada gereja yang bersikap antipati, ada yang menerima bahkan mengikuti trend yang berkembang demi mendapat kunjungan dari "jemaat" dengan selera yang umum. ${ }^{17}$ Praktik tersebut sudah mewabah dalam banyak gereja; membuat kemasan ibadah yang

\footnotetext{
${ }^{15}$ AG. Eka Wenats Wuryantai, "Digitalisasi Masyarakat: Menilik Kekuatan Dan Kelemahan Dinamika Era Informasi Digital Dan Masyarakat Informasi," Jurnal ILMU KOMUNIKASI 1, no. 2 (November 27, 2013), accessed Mei 21, 2015, http://ojs.uajy.ac.id/index.php/jik/article/view/163.

${ }^{16}$ Yohanis Luni Tumanan and Yohanis Luni Tumanan, "Ibadah Kontemporer: Sebuah Analisis Reflektif Terhadap Lahirnya Budaya Populer Dalam Gereja Masa Kini,” Jurnal Jaffray 13, no. 1 (March 16, 2015): 35, accessed April 23, 2015, http://ojs.sttjaffray.ac.id/index.php/JJV71/article/view/110.

${ }^{17}$ Ibid.
} 
sesuai dengan selera pasar. Inilah dunia di mana gereja hidup saat ini yang tidak sertamerta dapat diukur dari pola zaman para rasul sekalipun. David R. Ray yang dikutip Yohanis Luni Tumanan dalam Jurnal Jaffray mengatakan, ibadah kontekstual harus diimbangi dengan ibadah yang autentik juga, karena itu merefleksikan jemaat secara kultural. ${ }^{18}$ Pada akhirnya, gereja harus saling menghormati dan menghargai persoalan "selera" yang mengikuti pola perubahan dan perkembangan zaman.

Tantangan digitalisasi seharunya tidak dihadapi secara apatis, namun juga tidak serta-merta menjadikan teknologi menjadi tuan atas kehidupan, bahkan hingga pelayanan gereja. Menyikapi kemajuan teknologi tetap harus berpadanan pada konsep pelayanan dan pengembangannya secara biblikal. Mahasiswa sebagai bagian dari pergeseran nilai-nilai hidup tidak juga terseret pada arus sekularisasi yang menghilangkan cita rasa manusia rohani. Namun ironisnya, tidak sedikit mahasiswa yang terjebak pada penggunaan teknologi yang berlebihan, sehingga pada prosesnya mereka menjadi hamba teknologi bukan sebaliknya.

\section{Memetakan Tantangan dan Kebutuhan}

Tantangan dalam kehidupan kekristenan bukan sebuah hal baru, sehingga orang Kristen tidak perlu alergi bahkan menghindari tantangan. Embrio "lebih dari pemenang" bukan sebuah anugerah yang dilimpahkan begitu saja tanpa proses pematangan menuju kedewasaan iman. Justru pemenang hanya diperoleh dari sebuah medan laga atau pertempuran. Tantangan pelayanan gereja di masa sekarang tidak perlu dibandingkan dengan masa lalu atau yang akan datang, karena setiap masa memiliki kesulitan dan keunikannya sendiri-sendiri. Tantangan pelayanan yang ada sekarang harus dihadapi oleh mental kekinian.

Tantangan dunia dengan era digital telah meletakkan gereja pada pilihan mau berubah dan ikut maju atau hanya menjadi penonton seakan memelihara kesucian dengan pola konservativisme yang merugikan. Gereja telah memberikan responnya masing-masing terhadap berbagai perubahan tersebut; ada yang reaktif, proaktif dan apatis. Masing-masing sikap akan menjumpai implikasi dalam pelayanan mereka masing-masing. Namun sebagai lembaga yang menjunjung tinggi visi keunggulan Pentakostalisme, maka Sekolah Tinggi Teologi Intheos akan terus berupayan

\footnotetext{
${ }^{18}$ Ibid.
} 
menanggapi semua kemajuan teknologi tersebut secara positif demi memajukan pelayanan dan gereja yang dilayani.

Gereja harus memetakan tantangan tersebut, karena pada tantangan sejatinya terbungkus sebuah kebutuhan yang sudah tidak dapat lagi dijawab oleh produk yang lama. Pelayanan karunia pada masa para rasul bukan sudah usang dan tidak terpakai lagi, melainkan harus ada sikap untuk menanggapi sebuah bentuk baru yang belum pernah ada sebelumnya. Pemetaan tantangan akan membantu sebuah stimulasi pada kebutuhan gereja sehingga menghasilkan karunia-karunia yang lebih aktual sesuai dengan tantangan masa kini.

\section{Digitalisasi Karunia Pelayanan}

Perlukah ikut-ikutan untuk melakukan digitalisasi dalam pelayanan? Persoalannya kembali pada kebutuhannya akan seperti apa. Kebutuhan gereja di era digital bukan saja pada melakukan digitalisasi pelayanan yang ada, namun lebih kepada hasil apa yang didapat dari pemetaan tantangan yang ada. Hasil dari diskusi dan analisis penelitian kolaboratif ini menghasilkan sebuah bentuk karunia yang dulu sudah ada dan hanya beberapa saja dari para rasul yang melakukannya. Sepertinya latar belakang nelayan tidak akan menjadi alasan yang elegan untuk menghindari atau mengabaikan karunia yang satu ini, yakni menulis.

Para rasul yang berjumlah 12 tersebut hanya menghasilkan tidak lebih dari separuhnya adalah penulis Perjanjian Baru. Hanya beberapa saja yang karyanya dapat kita nikmati hingga sekarang. Indikasi ini memperlihatkan betapa persoalan menulis bukanlah hal yang baru di dunia pelayanan, karena para rasul, terutama Paulus telah melakukannya sejak dulu. Dapat dibayangkan kalau tidak ada satu pun dari para rasul yang "tergerak" untuk menulis. Sementara serangan eksternal terhadap gereja banyak terjadi lewat tulisan, seperti injil-injil yang dipengaruhi Gnostik. Selain itu juga literatur Yahudi yang meninggalkan kontroversi dalam kekristenan merupakan hasil dari karya tulis.

Karunia menulis merupakan hal yang unik, sekalipun semua orang bisa saja menulis. Persoalannya, bagaimana menciptakan tulisan yang menarik dan mempengaruhi. Di zaman digital sekarang ini hal menulis mungkin sudah menjadi hal yang biasa karena orang terbiasa berkomunikasi lewat bahasa tulisan melalui media sosial. Era digital menghasilkan tantangan yang besar bagi gereja, berupa ajaran-ajaran 
yang frontal menyerang kekristenan mudah sekali masuk di beranda orang-orang Kristen yang tidak terlalu kuat dalam imannya. Namun di sini lain tantangan ini telah menghasilkan kemudahan bagi dunia misi.

Kegiatan misi yang dilarang dalam bentuk penginjilan pribadi, baik door to door atau person to person, dapat dilakukan dengan cara melakukan posting pendapat secara "bebas" kepada siapa pun. Persoalannya kembali pada poin krusial, seberapa banyak orang yang tertarik ketika melihat dan membaca sebuah postingan. Ini yang akan menjadi stimulus berikut dalam penelitian ini. Setidaknya, tantangan era digital telah menghasilkan kesempatan untuk semua orang menyebarkan apa yang diyakininya untuk mempengaruhi orang lain; tentu dengan cara yang elegan.

Cara aktual yang dilakukan dalam perkuliahan Studi Pelayanan Karunia adalah menstimulasi mahasiswa untuk mengeksplor sesuatu yang ada di dalam dirinya, bisa saja itu ada dan tidak disadari selama ini, sehingga dapat menjadi senjata dalam memenangkan dunia. Kebutuhan gereja saat ini adalah bagaimnaa menyampaikan ajarannya kepada siapa saja tanpa harus melanggar aturan yang ada. Digitalisasi sistem informasi telah menolong setidaknya banyak orang untuk dapat melakukan "penginjilan" melalui tulisan yang dapat diunggah di berbagai media sosial ataupun situs akademis.

\section{Kesimpulan}

Pada akhirnya, melihat dan mempertimbangkan era yang semakin maju dengan teknologi digital-nya, maka gereja tidak boleh apatis atau gagal memanfaatkan peluang yang ada demi memajukan pekerjaan Tuhan. Masyarakat pada era digital adalah orangorang yang diperhadapkan pada segala sesuatu yang tersaji oleh gadget yang memberi aktualisasi hidupnya. Sajian itu dapat berupa hiburan dan informasi, gambar, video ataupun artikel. Setiap hari orang akan menikmati, melihat, membaca apa yang tersaji di gadget-nya, sehingga kebutuhan informasi menjadi sesuatu yang prinsip dalam era digital ini. Gereja diperhadapkan dengan masyarakat yang membutuhkan informasi, sehingga kebutuhan itu harus dipenuhi secara maksimal melalui karunia yang sesuai dengan kebutuhan itu. Gereja harus dapat mengaktualisasikan kebutuhan dalam bentuk pelayanan yang dapat menstimulasi karunia menulis. 


\section{Referensi}

Abineno, J. Ch. Penatua Jabatannya dan Pekerjaannya, Jakarta: BPK Gunung mulia, 1997

C, Frederick K. Saran-saran Praktis untuk Pelayanan yang Berhasil, Jakarta: Yayasan Pekabaran Injil, 1993

Enns, Paul. The Moody Handbook of Theology, Chicago, Ill.: Moody Press, 1996

F, Walter Bauer. Gingrich, Wilbur. and Danker, Frederick W. A Greek-English Lexicon of the New Testament and Other Early Christian Literature, Chicago: University of Chicago Press, 1979

Guthrie, Donald. Teologi Perjanjian Baru, 3 Jilid, Jakarta: BPK Gunung Mulia, 1997

Meidasari, Andi Faisal Bakti dan Venny Eka. "Trendsetter Komunikasi Di Era Digital: Tantangan Dan Peluang Pendidikan Komunikasi Dan Penyiaran Islam.” Jurnal Komunikasi Islam 4, no. 1 (June 1, 2014). Accessed August 31, 2017. http://jki.uinsby.ac.id/index.php/jki/article/view/35/29.

Putra,Eka Darma. Jurnal Pelita Zaman, Bandung: 1988

Sulu,Phill. M. Gembala dimata Jemaat, Malang:Gandum Mas, 2014

Sumarauw, Johny, Made Astika, and Made Astika. "Analisis Pendayagunaan KaruniaKarunia Roh Terhadap Pertumbuhan Jemaat Gereja Pantekosta Di Indonesia ElShaddai Makassar.” Jurnal Jaffray 13, no. 1 (March 18, 2015): 55. Accessed August 31, 2017. http://ojs.sttjaffray.ac.id/index.php/JJV71/article/view/113.

Tumanan, Yohanis Luni, and Yohanis Luni Tumanan. "Ibadah Kontemporer: Sebuah Analisis Reflektif Terhadap Lahirnya Budaya Populer Dalam Gereja Masa Kini." Jurnal Jaffray 13, no. 1 (March 16, 2015): 35. Accessed August 31, 2017. http://ojs.sttjaffray.ac.id/index.php/JJV71/article/view/110.

v.d.,Brink H. Tafsiran Alkitab Kisah Para Rasul, Jakarta: BPK Gunung Mulia, 2008 Wagner, Peter. Manfaat Karunia Roh, Malang: Gandum Mas, 2000 Wuryantai, AG. Eka Wenats. "Digitalisasi Masyarakat: Menilik Kekuatan Dan Kelemahan Dinamika Era Informasi Digital Dan Masyarakat Informasi.” Jurnal ILMU KOMUNIKASI 1, no. 2 (November 27, 2013). Accessed August 31, 2017. http://ojs.uajy.ac.id/index.php/jik/article/view/163. 